\title{
A METHODOLOGY FOR GEAR FATIGUE TESTS AND THEIR EVALUATION (PART 2)
}

\section{PETR MARŠÁLEK, VLADIMÍR MORAVEC}

VŠB-Technical University of Ostrava, Faculty of Mechanical Engineering, Department of Machine Parts and Mechanisms, 17. listopadu 15, 70833 Ostrava-Poruba, Czech republic, E-mail: petr.marsalek.st3@vsb.cz, vladimir.moravec@vsb.cz

\section{SHRNUTí}

Článek dává návod, jak statisticky zpracovat výsledky experimentálních zkoušek ozubených kol na pulsátoru. Za předpokladu zkoušení materiálu podle metody stair-case jsou uvedeny algoritmy, jak vyhodnotit pravděpodobnostní průběh meze únavy $v$ ohybu. Vyhodnocení je demonstrováno na reálných výsledcích únavových zkoušek.

KLIČCVÁ SLOVA: METODIKA, PULZÁTOROVÉ ZKOUŠKY, ÚNAVA, STUPŇOVITÁ METODA, PRAVDĔPODOBNOSTNÍ PRŮBĚH MEZE ÚNAVY V OHYBU

\section{ABSTRACT}

This article provides guidelines on how to statistically treat the results from single tooth fatigue tests. Assuming the methodology for testing is followed, algorithms are presented here to evaluate the probability plot of the fatigue limit in bending. The evaluation is demonstrated using actual results from fatigue tests.

KEYWORDS: METHODOLOGY, SINGLE-TOOTH FATIGUE, STAIRCASE, PROBABILITY PLOT OF THE FATIGUE LIMIT IN BENDING

\section{INTRODUCTION}

In the first part we demonstrated mechanisms for the design and performance of fatigue tests. Procedures were also presented for the design of the test specimen, shape of the test jaws and a suitable setting of initial values for testing the bending fatigue properties.

This second part will focus on the staircase methodology for fatigue testing. A specific example will be given of calculating the fatigue limit probability in bending from actual test results. At the conclusion of the article we introduce the complete results of testing performed on two materials, 18CrNiMo7-6 (1.7186) and $21 \mathrm{MnCrB5}-4$ (1.6587). Four specimens were produced from both of these carburizing steels with a rated degree of deformation min. 3:1 and quality MQ according to standard ISO [6]. Half of them were subject to shot peening with shot size of $0.6 \mathrm{~mm}$ with intensity ALMA type $A$ at least to the required hardness 59 HRC. This creates a thin surface layer with a significant residual compressive stress, which has a positive effect on increasing the fatigue properties [2]. From the test results it is possible to evaluate the benefit of shot peening and apply it in the future in gear calculations.

The parameters of all the test specimens are shown in Figure 1.

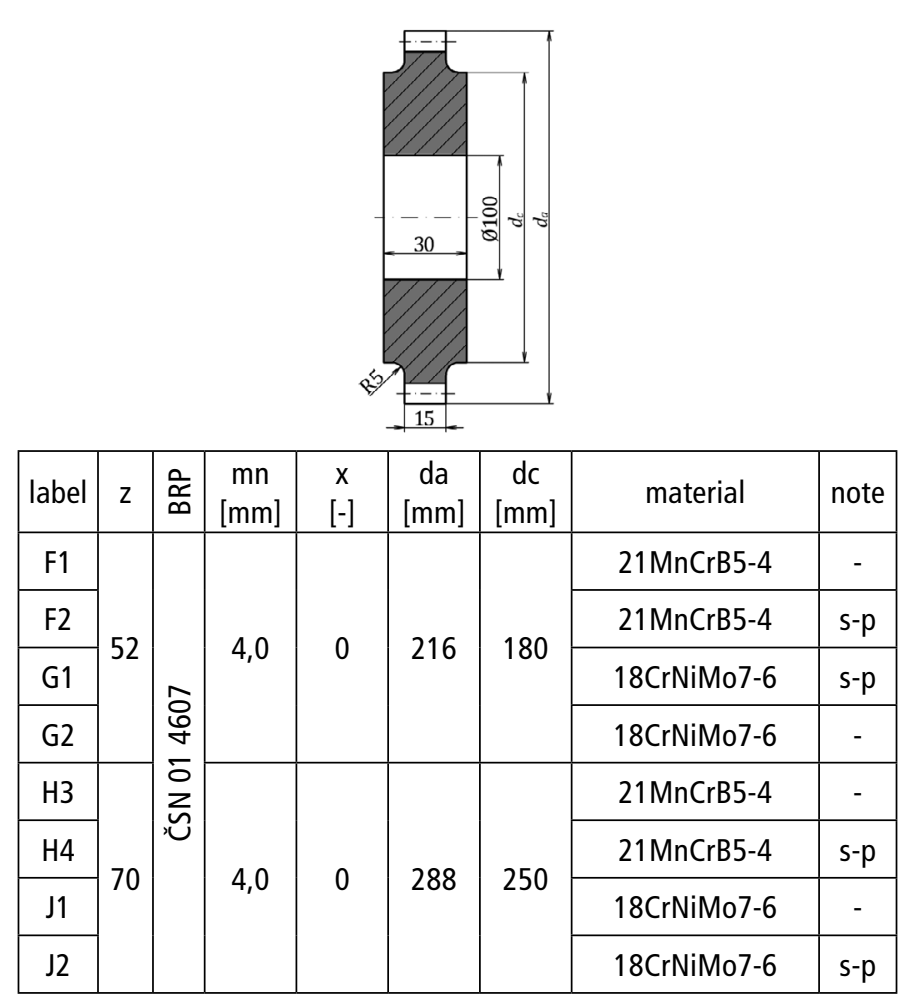

FIGURE 1: The characteristics of test specimens OBRÁZEK 1: Charakteristika zkušebních vzorků 
The tests were performed with a displaced repeating cycle on the Schenk PVT pulsator at the Tatra, a. s. dynamic testing laboratory. During the seven months of intensive testing a total of 111 experiments were performed on the eight specimens. The examination was based on a staircase method.

\section{PROCESSING THE EXPERIMENTAL}

\section{RESULTS}

A data file was obtained for statistical processing. Before evaluation, we excluded outlying results. These arose mainly due to incorrect choice of starting values at the start of testing. They can be identified, for example, using the median absolute deviation.

In the first phase of evaluation it is appropriate to convert the load to a stress in the gear tooth root fillet. For this we can use FEM, or conversion constant $K_{\mathrm{p}}$ given by equation (1).

$K_{\mathrm{p}}=\frac{Y_{\mathrm{Fa}} \cdot Y_{\mathrm{Sa}}}{b \cdot m_{\mathrm{n}}}=\frac{1,364 \cdot 2,003}{15 \cdot 4}$

$K_{\mathrm{p}}=45.61 \cdot 10^{-3} \mathrm{~mm}^{-2}$

The calculation algorithm for coefficients $Y_{\mathrm{Fa}^{\prime}} Y_{\mathrm{Sa}}$ is dependent on the geometry of the basic rack tooth profile, and the actual addendum modification coefficient $x^{\prime}$, diameter $d_{x^{\prime}}$ i.e. the point of contact between the jaw and the test sample, see Figure 2 . The solution coefficients are set forth in standards DIN [7] and ISO [6]. From the same figure it follows that the diameter $d_{\mathrm{x}}$ is significantly smaller than the tip diameter $d_{\mathrm{a}}$. Diameter $d_{\mathrm{x}}$ is also smaller than working diameter $d_{\mathrm{w}}$ due to the angle $\delta$.

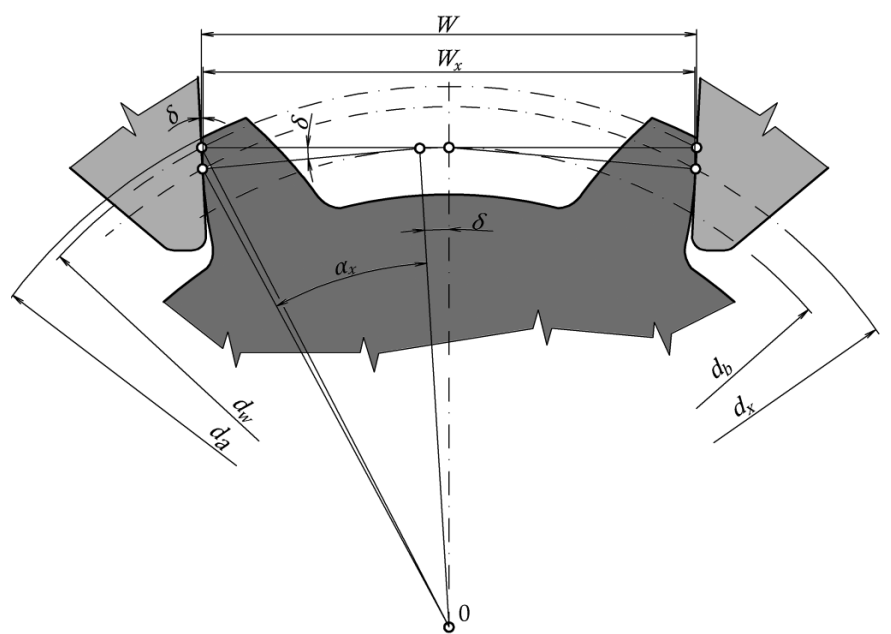

FIGURE 2: Diagram showing the clamping of the test specimen between the two jaws

OBRÁZEK 2: Schéma upnutí zkušebního vzorku mezi dvěma čelistmi
From Figure 2 we can also derive equations for calculating the diameter $d_{\mathrm{x}}$ that must be entered in place of $d_{\mathrm{a}}$ when calculating the coefficients $Y_{\mathrm{Sa}}$ and $Y_{\mathrm{Fa}}$.

$d_{\mathrm{x}}=\frac{d_{\mathrm{b}}}{\cos \alpha_{\mathrm{x}}}=\frac{195.456}{\cos 22,593}$

$d_{\mathrm{x}}=282.327 \mathrm{~mm}$

$d_{\mathrm{b}}=z \cdot m_{\mathrm{n}} \cdot \cos a_{\mathrm{t}}=70 \cdot 4 \cdot \cos 20$

$d_{\mathrm{b}}=263.114 \mathrm{~mm}$

$\alpha_{\mathrm{x}}=\arctan \left(\frac{W}{d_{\mathrm{b}}}-\delta\right)=\arctan \left(\frac{92,485}{263,114}-0,05236\right)$

$\alpha_{\mathrm{x}}=21,26^{\circ}$

$W=m_{\mathrm{n}} \cdot \sin \alpha_{\mathrm{n}}\left[\left(\mathrm{z}_{\mathrm{m}}-0,5 \cdot \operatorname{sgn} z\right) \cdot \pi+2 \cdot x \cdot \tan \alpha_{\mathrm{n}}+z \cdot \operatorname{inv} \alpha_{\mathrm{n}}\right]$

$W=4 \cdot \sin 20[(8-0,5 \cdot 1) \cdot \pi+2 \cdot 0 \cdot \tan 20+70 \cdot \operatorname{inv} 20]$

$W=92.485 \mathrm{~mm}$

$x^{\prime}=x-\left(\frac{W-W_{\mathrm{m}}}{2 \cdot m_{\mathrm{n}} \cdot \sin \alpha_{\mathrm{n}}}\right)=0-\left(\frac{92,485-92,53}{2 \cdot 4 \cdot \sin 20}\right)$

$x^{\prime}=0.01645$

$x^{\prime}=x-\left(\frac{E_{\mathrm{w}}-2 \cdot T_{\mathrm{w}}}{2 \cdot m_{\mathrm{n}} \cdot \sin \alpha_{\mathrm{n}}}\right)$

The notation used in equations $(2-7)$ is defined in the list of notations and abbreviations at the end of the article. When calculating actual unit corrections coefficient $x^{\prime}$, we can proceed in two ways. We can use equation (6), where we consider the average value measured over the teeth $W_{\mathrm{m}^{\prime}}$ or we can apply equation (7). In this case, we consider only the upper span over the teeth $E_{\mathrm{w}}$ and tolerance span over the teeth $T_{\mathrm{w}}$ that are commonly given in technical drawings.

\section{EVALUATION OF FATIGUE TESTS}

An example of fatigue limit evaluation is performed only for test specimen J1. The results for the other specimens are given in master thesis [2]. After the conversion of forces to stress, we create a new table of input values (Table 1). From these values we can produce a staircase chart as shown in Figure 3. During the testing of specimens it less often occurred that there was 
no damage to the tooth (empty circle), and therefore in Table 2 this case was evaluated using the staircase method. It is easy to recognize errors in testing procedures. After the fracture of a tooth, the next test will be performed at a lower level, and vice versa.

TABLE 1: Recalculated values of loads for specimen J1 TABULKA 1: Přepočtené hodnoty zatižení vzorku J1

\begin{tabular}{|c|c|c|c|c|}
\hline $\mathrm{n}$ & specimen & $\sigma_{\mathrm{m}}[\mathrm{MPa}]$ & $\sigma_{\mathrm{a}}[\mathrm{MPa}]$ & number of cycles \\
\hline 1 & J1 1-1 & 684 & 456 & $>3000000$ \\
\hline 2 & J1 2-2 & 730 & 502 & 171800 \\
\hline 3 & J1 3-3 & 730 & 502 & $>3000000$ \\
\hline 4 & J1 4-4 & 775 & 547 & 70400 \\
\hline 5 & J1 5-5 & 730 & 502 & $>3000000$ \\
\hline 6 & J1 6-6 & 775 & 547 & 79800 \\
\hline 7 & J1 7-7 & 775 & 547 & 154200 \\
\hline 8 & J1 8-8 & 730 & 502 & 273500 \\
\hline 9 & J1 9-9 & 684 & 456 & $>3000000$ \\
\hline 10 & J1 10-10 & 730 & 502 & $>3000000$ \\
\hline 11 & J1 11-11 & 775 & 547 & 51000 \\
\hline 12 & J1 12-12 & 775 & 547 & 686300 \\
\hline 13 & J1 13-13 & 730 & 502 & $>3000000$ \\
\hline 14 & J1 14-14 & 821 & 593 & 51000 \\
\hline 15 & J1 15-15 & 821 & 593 & 47700 \\
\hline 16 & J1 16-16 & 775 & 547 & 81500 \\
\hline
\end{tabular}

TABLE 2: Evaluation using the staircase method TABULKA 2: Vyhodnocení metodou stair-case

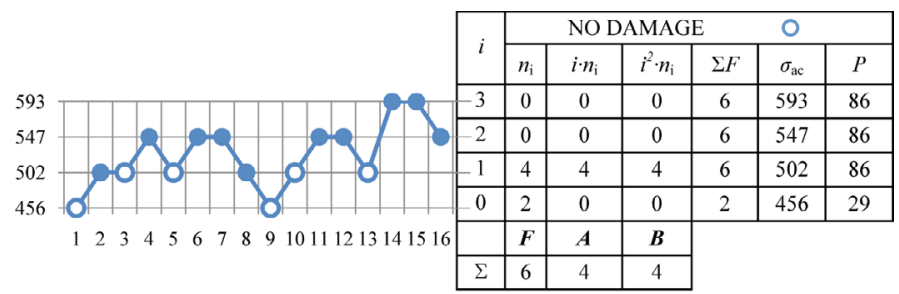

FIGURE 3: Chart of the staircase method OBRÁZEK 3: Graf stupňovité zkoušky

The median value of amplitude obtained using equation (8).

$\overline{\sigma_{\mathrm{ac}}}=\sigma_{\mathrm{ac} 0}+d \cdot\left(\frac{A}{F} \pm \frac{1}{2}\right)=456+45,61 \cdot\left(\frac{4}{6}+\frac{1}{2}\right)$

$\overline{\sigma_{\text {ac }}}=509 \mathrm{MPa}$

Here the width of level $d$ corresponds to conversion constant $K_{\mathrm{p}}$ given by equation (1). This fact follows from the test setting where level width was $1 \mathrm{kN}$. In order to calculate the standard deviation with sufficient precision, the inequality (9) must be satisfied.

$\frac{B \cdot F-A^{2}}{F^{2}}=\frac{4 \cdot 6-4^{2}}{6^{2}}=0.2 \ngtr 0.3$

In this case, inequality isn't satisfied. Even so, we attempted to calculate the standard deviation of amplitudes using equation (10).

$S_{\sigma_{\mathrm{ac}}}=1,62 \cdot d \cdot\left(\frac{B \cdot F-A^{2}}{F^{2}}+0,029\right)=1,62 \cdot 45,61 \cdot\left(\frac{4 \cdot 6-4^{2}}{6^{2}}+0,029\right)$

$S_{\sigma_{\mathrm{ac}}}=18.6 \mathrm{MPa}$

Values of standard deviations thus obtained can be considered as indicative only, and should not be separately used for extrapolation.

The last column in Table 2 indicates the probability of failure on level $I$, and is given by equation (11).

$P_{\mathrm{i}}=\frac{\sum F}{F+1} \cdot 100=\frac{6}{6+1} \cdot 100$

$P_{3}=86 \%$

where $\Sigma \mathrm{F}$ represents the accumulation of damaged or intact samples. Only the case which occurred less often is taken into account. A similar procedure is used when calculating the average amplitude or its standard deviation. Using this we can depict graphically the probability distribution shown in Figure 4 as substitution in equations (8) and (10) for the results obtained with single tooth fatigue test. Ideally, the substitution should correspond to the measured values. The vertical axis is the normal distribution quantile $u_{\mathrm{p}^{\prime}}$ which has a linear character. From Figure 4 it can be seen that the consensus is, in this case, only symbolic.

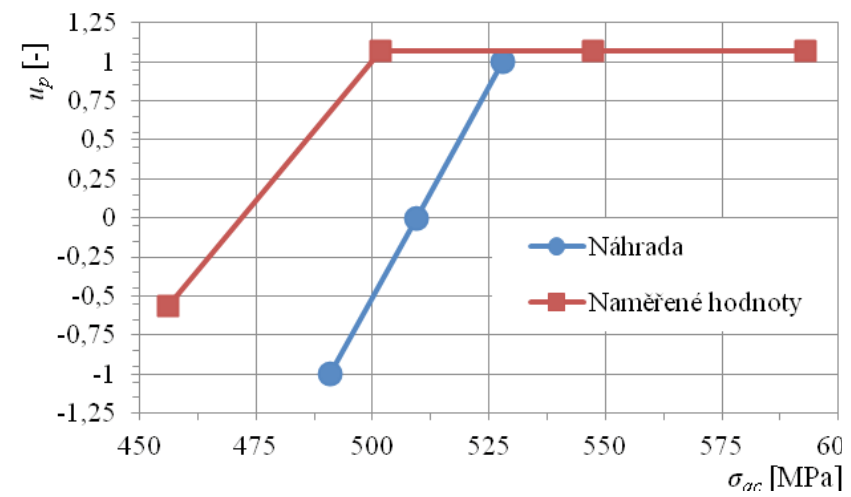

FIGURE 4: Plot of the probability distribution $\sigma_{\mathrm{ac}}$ for specimen J1 OBRÁZEK 4: Průběh rozdělení pravděpodobnosti $\sigma_{\text {ac }}$ vzorku J1 
Equations (8-10) are based on the staircase method according to the original work of Dixon and Mood [1]. At present this method is embodied in the standard ISO [4], which is valid for general engineering.

When tested with constant lower stress $\sigma_{\mathrm{d}^{\prime}}$ we are able from the Haigh diagram [3] to determine the value of the allowable bending fatigue stress $\sigma_{\mathrm{FE}}$ :

$\sigma_{\mathrm{FE}}=2 \cdot \overline{\sigma_{\mathrm{ac}}}+\frac{4}{7} \cdot \sigma_{\mathrm{d}}=2 \cdot 509+\frac{4}{7} \cdot 228$

$\sigma_{\mathrm{ac}}=1149 \mathrm{MPa}$

The same procedure was used with the other seven specimens. The procedure for calculating the amplitude using the staircase method is, however, quite time consuming and laborious. Therefore, we suggest an alternative method. It consists in principle in evaluating only the intact samples, i.e. those that showed no tooth damage after $3 \cdot 10^{6}$ cycles (empty circle), see Figure 5 . In this case it is possible to merge all the amplitudes from specimens with 52 and 70 teeth from the same material, which is not possible when using the staircase method. This is due to the increased number of levels influenced by the different geometry. Evaluation of average value $\overline{\sigma_{a c}}$ and standard deviation $S_{\sigma_{\mathrm{ac}}}$, is realized with a larger number of values, which in terms of statistics is much better [2]. To calculate these two values we can use the internal functions of spreadsheet programs such as Excel.

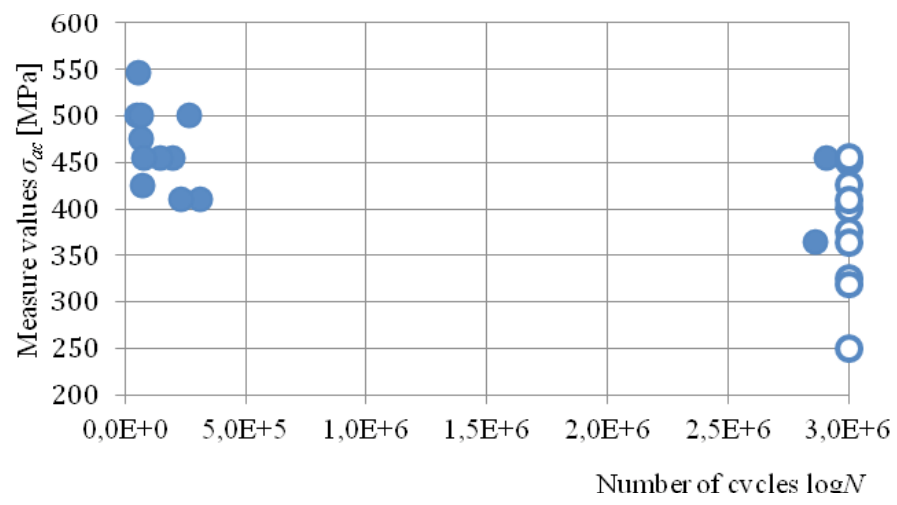

FIGURE 5: Separation of measurements on samples of material 18CrNiM07-6

OBRÁZEK 5: Separace naměřených hodnot na vzorcích z materiálu 18CrNiMo7-6

An overview of all the allowable stress numbers for bending obtained using the staircase method and alternative method for both tested materials is shown in Table 4.
TABLE 4: Allowable stress number for bending for $50 \%$ probability of failure [MPa]

TABULKA 4: Meze únavy v ohybu pro $50 \%$ pravděpodobnost vzniku poruchy [MPa]

\begin{tabular}{|c|c|c|c|c|c|c|c|}
\hline \multicolumn{2}{|c|}{21 MNCRB5 } & \multicolumn{2}{|c|}{ 18CRNIM07 } & \multicolumn{2}{c|}{ 21 MNCRB5 } & \multicolumn{2}{c|}{ 18CRNIM07 } \\
\hline s-p & - & s-p & - & s-p & - & s-p & - \\
\hline \multicolumn{3}{|c|}{ stair-case method } & \multicolumn{5}{c|}{ alternative method } \\
\hline 1425 & 1048 & 1445 & 1001 & 1382 & 1055 & 1293 & 918 \\
\hline
\end{tabular}

These results have probability of damage $50 \%$, similar to values in the standard ČSN [5]. However, comparing the results with equivalent material $14220(16 \mathrm{MnCr} 5)$ we find that the values in Table 4 for material not subject to shot-peening are about $30 \%$ higher. Based on this finding, use of the ČSN standard for the dimensioning of gears from carburizing steels cannot be recommended. On the other hand, standards DIN [7] and ISO [6] present allowable stress numbers for bending with a one percent probability of fracture damage. For comparison we can use relationships (6-8) from the first part of this article, or experimentally obtained standard deviations of the amplitudes $S_{\sigma_{\mathrm{ac}}}$, which can be matched with a standard deviation of fatigue limit in bending by educated estimation. Individual values from Table 4 can be converted using equation (13).

$\sigma_{\mathrm{FE} 1 \%}=\sigma_{\mathrm{FE} 50 \%}+u_{\mathrm{p} 1 \%} \cdot \overline{S_{\sigma_{\mathrm{ac}}}}$

where $u_{\mathrm{p} 1 \%}$ is normal distribution quantile and $\overline{S_{\sigma_{\mathrm{ac}}}}$ is average standard deviation from test results.

This gives the allowable stress number for bending with a similar probability as quoted in standards DIN and ISO, and we can proceed to their comparison with experimental results.

TABLE 5: Allowable stress number for bending for $1 \%$ probability of failure [MPa]

TABULKA 5: Meze únavy v ohybu pro 1\% pravděpodobnost vzniku poruchy [MPa]

\begin{tabular}{|c|c|c|c|c|c|c|c|c|c|c|c|}
\hline 21 MN CRB5 & 18CRNIM07 & \multicolumn{2}{|c|}{21 MN CRB5 } & 18CRNIM07 & \multicolumn{2}{|c|}{ 16MN CR6 } & \multicolumn{2}{c|}{ CARB. STEEL } \\
\hline \multicolumn{2}{|c|}{ experiment (staircase) } & \multicolumn{3}{|c|}{ experiment (Gauss) } & \multicolumn{2}{|c|}{ DIN [7] } & \multicolumn{2}{|c|}{ ISO [6] } \\
\hline s-p & - & s-p & - & s-p & - & s-p & - & s-p & - & s-p & - \\
\hline 1291 & 903 & 1311 & 856 & 1243 & 916 & 1154 & 779 & - & 920 & - & 1000 \\
\hline
\end{tabular}

\section{CONCLUSION}

This article demonstrates the procedure for evaluating the probability course of the fatigue limit in bending from the results of single tooth fatigue tests. Besides the calculation algorithms, an illustrative example of evaluation for two structural materials is also presented. The results are compared with the allowable 
value of equivalent materials according to standard ČSN [5], DIN [7] and ISO [6]. With regard to this comparison it can be stated that the experimental results for both materials are similar to those of the fatigue limit in bending in standards ISO and DIN. The still valid ČSN standard significantly underestimates the result. It also possible to evaluate the benefits of shot-peening with respect to improving the fatigue properties in bending of carburizing steels. This final operation has resulted in an increase in the fatigue limit of steel $21 \mathrm{MnCrB5}$ by almost $40 \%$, and in the case of materials $18 \mathrm{CrNiMo} 7$ by $50 \%$ ! Given the difficulty in performing tests, an increase in the fatigue limit by $30-40 \%$ for the strength calculation of gears from these materials can be assumed.

\section{ACKNOWLEDGEMENTS}

The results have been published with the permission of Tatra, a. $\mathrm{s}$.

\section{LIST OF NOTATIONS AND ABBREVIATIONS}

A

Constant for calculation amplitude of nominal stress number for bending [MPa]

$b \quad$ Facewidth [mm]

B Constant for calculation amplitude of nominal stress number for bending [MPa]

$d_{\mathrm{a}} \quad$ Tip diameter [mm]

$d_{\mathrm{b}} \quad$ Base diameter [mm]

$d_{w} \quad$ Pitch diameter [mm]

$d_{\mathrm{x}} \quad$ Contact jaw and specimen diameter [mm]

$E_{w} \quad$ Upper deviation of normal tooth thickness [mm]

$F \quad$ Constant for calculation amplitude of nominal stress number for bending [MPa]

$K_{\mathrm{p}} \quad$ Conversion constant $\left[\mathrm{mm}^{-2}\right]$

$m_{\mathrm{n}} \quad$ Normal module [mm]

$n \quad$ Numbers of samples [-]

$N \quad$ Numbers of cycles [-]

$P \quad$ Probability of damage [\%]

$s-p \quad$ shoot peening

$S_{\sigma_{\mathrm{ac}}} \quad$ Amplitude of nominal stress number for bending standard deviation [MPa]

$T_{w} \quad$ Normal tooth thickness tolerance [mm]

$u_{\mathrm{p}} \quad$ Normal quantile [-]

$W \quad$ Span measurement [mm]

$W_{\mathrm{m}} \quad$ Real span measurement [mm]

$x \quad$ Addendum modification coefficient [-]

$x^{\prime} \quad$ Real addendum modification coefficient [-]

$Y_{\mathrm{Fa}} \quad$ Form factor [-]

$Y_{\mathrm{Sa}} \quad$ Stress correction factor [-]

$z \quad$ Numbers of teeth [-]

$z_{\mathrm{m}} \quad$ Number of teeth measured over [-]

$\alpha_{\mathrm{n}} \quad$ Normal flank angle [ $\left.{ }^{\circ}\right]$ $\alpha_{t} \quad$ Transverse rack flank angle $\left[^{\circ}\right]$

$\alpha_{\mathrm{x}} \quad$ Contact jaw and a specimen angle [ $\left.{ }^{\circ}\right]$

$\delta \quad$ Slope support surface of jaw angle $\left[^{\circ}\right]$

$\sigma_{\mathrm{a}} \quad$ Amplitude stress [MPa]

$\sigma_{\mathrm{d}} \quad$ Lower stress [MPa]

$\sigma_{\mathrm{ac}} \quad$ Amplitude of nominal stress number for bending [MPa]

$\overline{\sigma_{\mathrm{ac}}} \quad$ Amplitude of nominal stress number for bending mean value [MPa]

$\sigma_{\mathrm{FE}} \quad$ Allowable stress number for bending [MPa]

$\sigma_{\mathrm{m}} \quad$ Mean stress [MPa]

\section{REFERENCES}

[1] DIXON W. J. \& MOOD A. M. (1948). A Method for Obtaining and Analyzing Sensitivity Data. Journal of the American Statistical Association. 43(241), p. 109-126.

[2] MARŠÁLEK P. (2008). Návrh metodiky a vyhodnocení únavových zkoušek ozubených kol. Unpublished Master thesis. Ostrava: VŠB-TU Ostrava, Fakulta strojní, (in czech).

[3] MORAVEC V. (2008). Posouzení únosnosti ozubených kol pulsátorovými zkouškami. Zpracováno v rámci projektu 1 M0568 "Výzkumné centrum automobilů a spalovacích motorů Josefa Božka II". D3-VCJB 3.3.3/2008 Ostrava, 16 p. (in czech)

[4] British Standards Institution. (2003). Metallic materials Fatigue testing - Statistical planning and analysis of data. BS ISO 12107. London

[5] Úřad pro normalizaci a měření. (1988). Pevnostní výpočet čelních a kuželových ozubených kol - Část 5: Meze únavy a údaje o materiálech. ČSN 01 4686-5. Praha.

[6] Český normalizační institut. (2005). Výpočet únosnosti čelních ozubených kol s prímými a šikmými zuby - Část 5: Údaje o pevnosti a kvalitě materiálů. ČSN ISO 6336-5. Praha.

[7] Deutsches Institut für Normung e. V. (1987). Tragfähigkeitsberechnung von Stirnrädern - Teil 5: Dauerfestigkeitswerte und Werkstoffqualitäten. DIN 3990-5. Berlin. 